\title{
Verbal Manifestation of Critical Thought: Transversal Study from Age 10 to 18 in France
}

\author{
Auriac-Slusarczyk Emmanuèle ${ }^{1, *}$, Fiema Gabriela ${ }^{2}$, Pironom Julie ${ }^{1} \&$ Belghiti Karima $^{3}$ \\ ${ }^{1}$ Université Clermont Auvergne, ACTé, F-63000 Clermont-Ferrand, France \\ ${ }^{2}$ Groupe de recherche sur l'éthique et l'éducation éthique, GREE, Université de Montréal, Montréal, Québec, Canada \\ ${ }^{3}$ Laboratoire de Recherche en Langues, littérature, communication et didactique. Sidi Mohamed Ben Abdellah \\ University, Fes, Morocco \\ *Correspondance: Université Clermont Auvergne, ACTé, F-63000 Clermont-Ferrand, France. Tel: 33-04-7331-8794. \\ E-mail: emmanuele.auriac@uca.fr
}

Received: October 17, 2017

Accepted: November 16, 2017 Online Published: November 29, 2017

doi:10.5430/wje.v7n6p38

URL: https://doi.org/10.5430/wje.v7n6p38

\begin{abstract}
The article studies the verbal manifestation of critical thought in a school context. Four modes of thought - logical, creative, responsible, and metacognitive - accompanied by six epistemological perspectives, are studied from 1,730 pupils turns to speak analyzed in eight class groups. The pupils dialog about freedom. Quantitatively and gradually the collective thought gives the lion's share to the manifestation of logical, followed by creative and then responsible thought, and very little to that of metacognitive thought. The study reveals a significant developmental effect for logical and responsible thought - to the advantage of the girls. While each mode of thought evolves following its own developmental path, the epistemological congruence that emerges between the logical and responsible modes of thought on the one hand and responsible and creative on the other seems perhaps debatable. The results lead to a pedagogic proposal which consists in proposing to introduce a cognitive activity of doubt, not spontaneously adopted by the pupils, to favor the advent of a form of critical thinking more balanced as concerns the modes of thoughts of which it composed.
\end{abstract}

Keywords: development; philosophy; critical thought; responsibility; creativity; logic; metacognition

\section{Introduction}

The present study, carried out in the context of an international research project (Note 1), contributes to analyzing the development of critical reflective thought between the ages of 10 and 18 as measured from verbal data obtained through a discursive community constructed for the needs of the research. The pupils, attending schools in France, are not involved in any pedagogic program.

Critical reflective thought at school and its development are given varied definitions to make it analyzable (Daniel, 2005; Auriac-Slusarczyk, Adami \& Daniel, 2010; Baffrey-Dumont, 2000; Harpaz, 2010). Associated with autonomy (Cuypers \& Haji, 2006), intellectual vigor, stabilizing learning (Peters, Smith \& Smith, 2002; Torff, 2006), favoring enlightened moral decisions (Darling, 2002, 2006; Fong, 2002, Thomas, 2001), it is not defined in one-dimensionally either by psychologists or philosophers. Five philosophers - John McPeck (1981), Robert Ennis (1993), Harvey Siegel (1988), Richard Paul (1992), and Matthew Lipman (1988) - whom Ralph Johnson names "The Group of Five" (see Harpaz, 2010) -have developed conceptions that have been taken up again, exploited, and discussed (Harpaz, 2010 op.cit.; Daniel \& Auriac-Slusarczyk, 2011; Daniel \& Auriac, 2011; Lipman, 2003). Thus, it is known that critical thought involves complex abilities which, connected to the maturation of awareness (Ennis, 1993), orient enlightened decisions. Supposedly, on the social level the critical thinker's inclination to collaborate distance him from his strictly personal interests (Paul, 1992 op.cit., 1993a); whilst the skeptical dimension comes into action to identify obsolete beliefs, supported by the varieties of academic knowledge (McPeck, 1994) which give access to the culture's epistemic past that is indispensable for forming an educated moral person (Arendt, 1972). So in education everyone agrees on the necessity of reinforcing the capacity to reflect and holds it to be obligatory to practice complex, logical, creative, and responsible thinking from the earliest years to make the individual's thought explicit 
in its foundations (Lipman, 1988 op.cit., 2003, op.cit.) and favor the development of self-corrective and metacognitive intellectual autonomy.

But can complex thought really be measured? What kind of modeling should be chosen to appraise and educate in the $21^{\text {st }}$ century? Collaborating to measure complex thought matters since the cogency and proper working of the democratic form of government depend on its development (Lipman, 2003 op. cit., Paul 1993b). As others before us (Daniel, Lafortune, Pallascio, Splitter, Slade, \& De la Garza 2005; Daniel \& Gagnon, 2011) we shall give thought to developing tried and tested modeling in education; while avoiding the reductionism that would have us believe that the (mathematical, statistical) measuring necessary for psychology as science (Piaget, 1971) can be a substitute for theory(Note 2), our contribution should be seen as a contribution to general thinking on the subject.

\section{Theoretical Framework}

The fruit of international research (Note 3) (Daniel, 2005 (Note 4) op.cit.; Daniel et al., 2005, op.cit.), the modeling used in this study characterizes how the complex thought of pupils of 4 to 12 years develops from its origins. Initially finalized from studying the verbal expressions of pupils philosophizing aged 11-12 (Daniel et al., 2005, op.cit.), it is suitable for describing the development of the dialogical critical thought of philosophizing pupils (Daniel \& Gagnon, 2011, op.cit.) or for characterizing the critical dialogical contents of a philosophy workshop (Daniel \& Fiema, 2017a/b). Applying it in secondary education introduces an interesting issue as to the levels of articulation between the four modes of thought targeted: logical, creative, responsible, and metacognitive after the age of 10 (Daniel, 2017; Daniel, Belghiti \& Auriac-Slusarczyk, 2017).

We shall situate the developmental psycholinguistic perspective that initially concerns our measure of cognitive and language development. We shall then indicate in what ways it is advisable to validate the modeling, rule on the evolution of dialogical critical reflective thought at the stage of formal (Inhelder \& Piaget, 1955) and post-formal though (Baffrey-Dumont, 2000, op.cit.). Quite particularly, we shall enlarge on the need to take a second look at the notions of creativity and metacognition, which, owing to our results, will benefit from further discussion.

\subsection{Developmental Psycholinguistic Perspective}

Historically, the measurement of thought has fallen in the field of psychology, even if man long before considered measuring his cognitive processes (Note 5) to be useful. The present issue of having measurements and evaluations for the human community poses the difficulty of defining whether knowledge is constructed from past knowledge (Knowledge building) or created from singular originalities (Knowledge creation). Some prefer to describe the development of collective knowledge to work directly for the well-grounded good of the collectivity (Bereiter and Scardamalia, 2014) - the benefits for individuals (raising everybody's level to a pre-established standard) becoming less crucial.

On the educational level the question is important. Measuring intelligence serves the community's interests to verify the normalization of a population's from individual scores (Binet \& Henri, 1895, see Fagot, 2000), to see if humanity is progressing, stagnating, or maybe regressing (Huteau, 2001a). For these reasons the relations between intelligence and politics are often tense, sometimes radical - the 1920s in the United States being marked by an aberrant use of tests - whilst French researchers reported more positive (albeit stormy) findings between intelligence and school, the term performance being less stigmatizing (Huteau, 2001b, p.11).

\subsubsection{Mathew Lipman's Program: Collective Thought in Actuality}

The philosophy program for young people, developed all over the world for over fifty years by Matthew Lipman (see Daniel, 1992/1997; Leleux, 2005; Gregory, Hayes \& Murris, 2017) is aimed at the collective level. The evaluation measures classes of pupils and not individuals (subjects, pupils), which researchers in France have adopted when studying discourse communities in class (Bernié, 2002; Jaubert \& Rebière, 2000): emphasis is placed on the collective dimension. Seen in this way, the psychologist recognizes the Vygotskian model, which sees development as a historico-cultural fact based on processes first shared inter-psychically before being mastered intra-psychically (Vergnaud, 2000, Bronckart, 1985, 1997, 2003; Bronckart, Johan-Steiner, Panofsy, Piaget, Scheuwly, Vygotski, Wertsh, 1985; Rochex, 1997).

\subsubsection{Taking a Second Look at and Structuring Piaget and Vygotsky}

The development models borrow readily from Vygotsky's model to complement Piaget's (Brossard and Fijalkow, 1998) without coming down for either stagist preponderance or impact of adult scaffolding correcting the stagist conception. Harpaz (2010, op.cit.) indicates that wanting to decide between an imitation and an 'individualist' model 
does not make much sense in education. Choosing between Piaget or Vygotski is not what matters but structuring both models without belittling the validity of the opposition novice/expert that is useful for describing development (Coirier, Gaonac'h \& Passerault, 1996; MacArtur, Graham \& Fitzgerald, 2006). But the theoretical tensions for describing development persist: wanting to theorize development obliges one to consider the contributions of the schools of thought - whether Piagetian (Piaget, 1971 op.cit., 1974) or Vygotskian (Vygotski, 1934/1997). It is not so much a question of opposing novices (children) and experts (adults) as of understanding how the dialogics is expressed - the distribution of the actions and their effects shared within educational activity.

\subsubsection{Verbalizing: The Dialogical Dimension at Work}

The development of thought cannot do without modeling the associated development of language (Karmiloff-Smith, 1979, 1992, 1994; Bautier \& Rochex, 1999), not by considering it as a simple vehicle of thought but as an active party in intellectual development (Esperet, 1979; Sorsana, 1999). Language philosophy also considers this dialogical dimension (Descombes, 2013, 2014) connected to the mobilization of cognitive processes underlying language use (Espéret, 1990, 1991). Taking the dialogical dimension into consideration amounts to knowing what to identify in authentic speech (Auriac-Slusarczyk \& Colletta, 2015; Simon \& Tozzi, 2017) - which discourse pragmatics has been studying for many years (Clark, 1996; Bernicot, Caron-Pargue \& Trognon, 1997). While they are well practiced in pragmatic analyses (Ghiglione \& Blanchet, 1991; Ghiglione, Kekenbosk, Landré, 1995) the researchers avoid projecting a model on children's discourse; they aim for neutrality (Auriac-Slusarczyk \& Fiema, 2013; Daniel, Pettier \& Auriac-Slusarczyk, 2011). Nonetheless, the interpretation is still imprisoned in a history, a culture (Arendt, 1972 op.cit., 2002, op.cit.) and adulto-centrism remains a possible pitfall when studying thought. Thus, developmental psycholinguistics recommends reliable data reusable by the scientific community (Auriac-Slusarczyk \& Leblay, 2010; Léon, 2008; Williams, 2005; Cappeau \& Seijido, 2005b see Smale, 2010).

It is known that discursive enchainment varies depending on the entourage, which is documented as concerns parental influences (Bernicot, Veneziano, Musiol, \& Bert-Erboul, 2010; Marcos, Salasar-Orvig, Bernicot, Guidetti, Hudelot, \& Préneron, 2004; Veneziano, 1999; Espéret \& Guibourg, 1988), and studied in school context (Auriac-Peyronnet \& Daniel, 2002; Auriac-Slusarczyk, 2010). Human language use works through language games (Wittgenstein, 1921), and what is between turns to speak is what ought to be studied (Trognon \& Brassac, 1992; Salavar-Orvig \& Hudelot, 1989). Dialogic strategies depend on interlocutory contexts: between a Socratic dialog adulto-centered - and a dialog between teenagers the strategies differ.

\subsection{Presentation of the Modeling Exploited}

The widely-published modeling we exploit (Daniel, 2013 or Daniel, Belghiti \& Auriac-Slusarczyk, 2017, op.cit. for presentations) will be given a summary description.

\subsubsection{Four Modes of Thoughts}

The four modes of thought targeted - logical, creative, responsible, and metacognitive, account respectively for multi-varied factors more or less studied (see our introduction): a) the logical mode (including formal and informal logic) is necessary to define the problem, to conceptualize and to argue; $b$ ) the creative mode has to be involved to give a structure to the criticism to be articulated: whether questioning certainties, exploring alternative points of view, creating original relationships or transforming perspectives, it is the creative mode that awakens awareness of a cognitive conflict, which is the first step in the reflective process; c) for criticism to be dialogical or constructive, the responsible mode is brought into play such that thinking finds a balance between the right to free expression and the responsibility of doing so with empathy, and it roots the evaluation of actions and principles in the objective of a common good; d) the meta-cognitive mode is mobilized when pupils suspend their judgment, reflect, and revise their own points of view in order to correct or improve them.

\subsubsection{Six Epistemological Perspectives}

To illustrate the increasing complexity of the process, we referred to six epistemological perspectives: Egocentricity, Post-Egocentricity, Pre-Relativism, Relativism, Post-Relativism and Inter-subjectivity (E, PE, PrR, R, PoR and I). These epistemological perspectives are the manifestations of pupils' representations of the world, from the simplest to the most complex: are their representations of the world and life concrete and self-centered (Egocentricity)? are they generalized and oriented toward others (Relativism)? are they abstract and motivated by a common good (Inter-subjectivity)? The appendix details these various perspectives for the reader, as applied to the modes of thought in Daniel's model (from Daniel, 2013, op.cit.) 


\subsubsection{Reflection on the Modeling Exploited}

Calculated from percentages representative of the modes of thought and their associated epistemological perspectives the empirical studies show a non-linear development: each period seems to reorganize knowledge, doubts, and contradictions within an enriched, transformed form of thought (Daniel \& Fiema 2017), as the Vygotskian or Brunerian models appear to be more suitable than the Piagetian model to describe this lack of linearity. Furthermore, the compilation of the results obtained shows the added value of logical thought at the very beginning of the school career, to the progressive profit and in line with the development of the other modes of thought - metacognitive remaining weakly represented (Daniel \& Gagnon, 2016; Heinzen, 2014).

The question of how the hierarchization of the six epistemologies is structured remains open. Are the six epistemologies constant degrees or do they come under an ordinal scale? Should the mobilization rate for each mode of thought be considered in relation to the developmental threshold, the specificity of the dialogical exercise, or the specificity of each mode of thought - logical, creative, responsible, metacognitive? Studies postulate that the manifestation of reflective thought only occurs at the stage of maturity for young adults in a university context (King \& Kitchner, 1994) - confirming the weak development of critical thought from adolescence (Berland \& McNeill, 2010; Kuhn, 2009; Kuhn \& Pease, 2008; Kuhn, Cheney \& Weinstock, 2000). Even among cultivated adults few make use of critical thought (Flores, Matkin, Burbach, Quinn \& Hearth, 2012; Forges, 2013; King \& Kitchener, 2011; Lechasseur, 2015) which seems to need active stimulation to develop - including at university (Tabak \& Weinstock, 2008).

\subsection{Conditions for the Development of Creative and Metacognitive Thought}

For the purposes of this article we give more special attention to two modes of thought - creative thought, less studied, and metacognitive thought, weakly represented.

\subsubsection{The Question of Creativity}

The study of creativity in education is not recent (Beaudot, 1969). Measuring creative thought has entailed the production of evidence (Wilson, Guilford \& Christensen 1953; see Beaudot, 1969, op.cit.). Tests - the best known being Torrance's (TTC, 1974, see Villalba, 2008; Besançon, Bardiot \& Lubart, 2011 for reviews) - have oriented towards a complex articulation between creativity and logic. Research into creativity in a schooling context is renewing itself (Plucker, Beghetto \& Dow, 2010; Plucker \& Beghetto, 2015; Beghetto \& Plucker, 2016) joining reasoning and creativity together (Kaufman \& Baer, 2016). It is acknowledged that creativity is a superior capacity (Binet, 1921, op.cit., Besançon, Guignard \& Lubart, 2006). Creativity is often associated with bringing divergent, exploratory or convergent, integrative thinking into play and seems to involve developmental peaks at the ages of 5 , 10, and 13 (Lubart, Besançon \& Barbot, 2011). For certain authors logical and creative thought only differ by degree and not by nature (Slade, 2000), and for Lipman sensible creative thought is "not made otherwise" than logical thought aimed at the truth but organized differently (Lipman, 1995, p.233). Creativity may favor dissent, where logic prefers to base itself on the doxa or episteme. The dialogs based on logic which "yet, does not stop them from leaving a space for creative thought" (Lipman, 1995, p.251). Creativity manifests itself less regularly than logic.

\subsubsection{The Question of Metacognition}

John H. Flawell is associated with the works on metacognition (Flawell, 1976, see Bruchon, 2005; Derycke \& Bautier, 2005). Sometimes called "knowledge of knowledge" (Wolfs, 2005) - definition of the 1970s - this term reveals Flawel's idea that defended knowledge as a process never stabilized and subject to what is named re-description (Karmiloff-Smith, 1992, op.cit.). The idea of potential is what characterized metacognition. The conceptualization goes beyond the practical - not always verbalizable - outcome, and must not be confused with consciousness (Pons, Doudin, Martin, Lafortune \& Harris, 2004, pp.23-25). From the movement towards consciousness, on the other hand, arises the potential, which if it is explicative may be actualized in metacognitive performance. It is frequently overlooked that metacognition corresponds to controlling one's cognition: it has a motive; it is hetero- or self-corrective, and is only developed in the face of error, failure, or obstacle (Noël, 1991, in Baffrey-Dumont, 2000, op.cit.). It does not regularly accompany intellectual activity but springs up as needs must: it should be considered to be a drive in the Bergsonian sense of active intelligence (Worms, 2017) that depends on a catalyst(Note 6) that favors the "retour réflexif (self-assessment)" (Wolfs, 2005, op.cit.). Some recommend its early development (Khun and Pease, 2006), but because it can be mobilized explicitly via teaching (Lafortune \& Robertson, 2004); others wonder critically about the dependence between consciousness and metacognition in the course of psychogenesis (Thommen \& Rimbert, 2005; Lafortune \& Roberston, 2004; Pons, Doudin, Martin, Lafortune \& Harris, 2004, op.cit.). 


\subsection{Hypotheses}

Based on the postulate that the class groups represent a developmental age our hypotheses are as follows:

(H1) It is verified whether the 8 groups are different from one another and whether the modes of thought - logical, creative, responsible, and metacognitive - are increasingly the objects of psychological investment as the subjects mature in years.

(H2) On the basis of the degrees of epistemological perspectives psychologically invested at this age it is verified if the four modes of thought are mobilized congruently. In other words, can the development of a manifestation of logical thought be considered in the same way as the manifestation of creative thought by the yardstick of their epistemological deployment?

\section{Methodological Framework}

The research is aimed at confirming manipulated variables (the six epistemological perspectives and the four modes of thought - logical, creative, responsible, and metacognitive) long tried and tested within the modeling elaborated (see 2.3.). It intends to account for the meaningful link between the actualization of the modes of thought and verify whether the epistemological perspectives evolve gradually (or not) as the pupils grow older.

Thus, for each mode of thought the six perspectives are coded in the form of an ordinal scale ( $\mathrm{E}<\mathrm{PE}<$ PreR $<\mathrm{R}<$ PostR $<$ IS; where $<$ means less than) without at first verifying whether the gap between degree is the same size: the point is to ask oneself how the epistemology perspectives that apply to each mode of thought operate. The effect of the age on the epistemological degrees of the four modes of thought is then studied by means of cumulative logistic regression analyses. Furthermore, the gender factor is controlled for each analysis.

\subsection{The Subjects}

The pupils attended three urban zone schools (primary, junior and senior secondary school), in a semi-favorized sector in France which have accepted to host the experimentation. The classes each comprise 18 to 25 pupils depending on the classes.

Table 1. Distribution of Pupil Numbers by Class

\begin{tabular}{lll}
\hline Age & $\begin{array}{l}\text { Level/class } \\
\text { in France }\end{array}$ & $\begin{array}{l}\text { Number } \\
\text { of pupils }\end{array}$ \\
\hline $10-11$ & CM2 primary & 25 \\
$11-12$ & $1^{\text {st }}$ junior & 22 \\
$12-13$ & $2^{\text {nd }}$ junior & 18 \\
$13-14$ & $3^{\text {rd }}$ junior & 23 \\
$14-15$ & $4^{\text {th }}$ junior & 24 \\
$15-16$ & $5^{\text {th }}$ senior & 20 \\
$16-17$ & $6^{\text {th }}$ senior & 31 \\
$17-18$ & Terminal senior & 25 \\
\hline
\end{tabular}

\subsection{The Activity Proposed}

The activity's goal was to confront commonplace pupils on a debatable topic ordinary enough not to put any pupil in difficulty, and sufficiently accessible for different ages over the span of 10 to 18 years.

\subsubsection{Conditions of transfers, theme for discussions}

A large format notice is presented to the pupils obliging them to adopt a position regarding contradictory opinions from fictitious pupils whose positions are summarized (example: being free is "not being in prison" (Elodie); the notice shows the question to be asked: "what about you, what do you think? What does "being free" mean to you? see figures 1 and 2 below) After collecting each pupil's position in the first session the discussion session is then started in each group. The second session's exchanges of views constitute the corpus analyzed.

The following corpus extracts indicate how the discussion gets under way. 
now let's set going so I told you the subject today is freedom being free what does it mean for you? To help you think a bit a little notice has been prepared for you l'll read to you what's written here being free is doing what I like being free means living without any law being free means shop-lifting without getting caught being free means having something to eat being clothed living in a house being free means not being in prison being free means travelling when you want to being free means thinking and being able to say what you think being free means buying branded clothes playing on the play-station watching the TV when you want being free means living in the wild like wild animals being free means living like Gypsies travelling in caravans without ever going to school being free means being happy together and the last being free is doing what you like with your life, so what does being free mean for you? Do you or do you not already agree with some of these affirmations? Yes, you'd like to say something? Let's take the first one, being free is doing what I like, is that what freedom means for you? Yes

Figure 1. Starting a Discussion in the 12/13 Years Group

To give an example, here is the start of the discussion in the 13/14 group (Note 7).

I'll read you propositions of pupils from three countries who I've who I've who talked about pardon about er what's being free so being free means ...[idem above]... wants from his life what do you think? What's freedom for you? Yes?

Figure 2. Starting a Discussion in the 13/14 Years Group

\subsection{The Coding for Turns to Speak}

Certain turns to speak occasion no coding. These are brief interventions (- yes, -no, - yes, - eh well, - ah yes - ah that'd be cool - well, alright), the interruptions producing repetitions, and the interventions completing a thought activated before without modifying the activated reasoning. In the following example 1, turn to speak 168 of pupil no. 25 (a boy) is coded as a logical thought, type relativiste and creative thought, type egocentric. The turns to speak TS169/TS170/TS171 of an unrecognized pupil, of pupils no. 23 (girl) and no. 25 are considered to be specifying the thought and consequently are not coded.

TS 168/M-25: sorry the rent for my home it costs four hundred Euros exactly and every month four hundred Euros four hundred Euros four hundred Euros you pay every time

TS 169/ pupil: and the taxes?

TS170/F-23: and well yes and how can you eat then?

TS 171/M-25: everything's included

Example 1: supporting verbalization for coding thoughts

In the second example, reporting the turns to speak TS1, TS3, TS5, and TS7, the pupil, girl, no. 23 (F-23) starts the discussion off, then the thoughts of pupil no. 23 and then no. 17 (boy, M-17) are coded for TS7 as complement to TS5 (non-coded) as egocentric type logical thought, and for TS3 as relativist type logical thought.

TS1/F-2: well as for me being free is well I think Elodie's right it's loving one another and being happy together and doing what you want what I like

TS3/F23: well because hum well it's like that you're free you do what you want

TS5/F-23: doing what I like

TS7/F-23: hmm because I can do anything

Example 2: support verbalization for coding thoughts

Thus the coding of the turns to speak only takes the thoughts verbalized by the pupils into account. 


\section{Results}

\subsection{Description of the Corpus}

In total the verbalizations consist of 3,047 turns to speak, fairly equally distributed between the class levels (table 2). Among these 3,047 initial turns to speak, 1,730 turns to speak -exclusively pupils' - are studied. They are analyzed by means of the grid that crosses the four modes of thought to which an epistemological perspective is attributed (numbered 1 to 6, see appendix 1). As 816 turns to speak are not coded, the study concerns 914 coming under one of the four epistemologically situated modes of thought. As a turn to speak may come under several modes of thoughts, there are 1,426 codings, in the end, that render the whole of the dialogical critical thought verbalized by the pupils. The coding is double-blind: 339 codings ( $20 \%$ of the turns to speak, pupils) have led to a few revisions (Note 8 ) both assessors always having been able to reach a negotiated agreement. Table 2 below gives the number of turns to speak, the total of the discussions - corresponding to the pupils' turns to speak, and the number of pupils who express themselves.

Table 2. Speech Numbers: Total, Pupils, Analyzed/Coded and Rate of Pupil Participation

\begin{tabular}{llll}
\hline Ages/Classes & $\begin{array}{l}\text { Number of total } \\
\text { interventions }\end{array}$ & $\begin{array}{l}\text { Number of pupil } \\
\text { interventions } \\
\text { (Note 9) }\end{array}$ & $\begin{array}{l}\text { Number of pupils } \\
\text { expressing } \\
\text { themselves }\end{array}$ \\
\hline 10-11 YEARS & 316 & 170 & 16 \\
$11-12$ YEARS & 395 & 194 & 15 \\
12-13 YEARS & 427 & 243 & 11 \\
13-14 YEARS & 381 & 237 & 12 \\
14-15 YEARS & 379 & 213 & 9 \\
15-16 YEARS & 354 & 239 & 9 \\
$16-17$ YEARS & 405 & 231 & 19 \\
17-18 YEARS & 389 & 203 & 10 \\
\hline
\end{tabular}

Within the pupil interventions (see table 2) 10\% express themselves only once and the same proportion do so over 40 times (including three pupils, ID64, ID100, and ID73 over 80 turns to speak, see figure 3). Apart from these extreme cases, with a mean of 16.80 turns to speak per pupil and a median of 9 for the sample the majority express themselves under ten times, a quarter of them four times, another quarter over 22 times. For a detailed display of the corpus we refer the reader to appendix 2 .

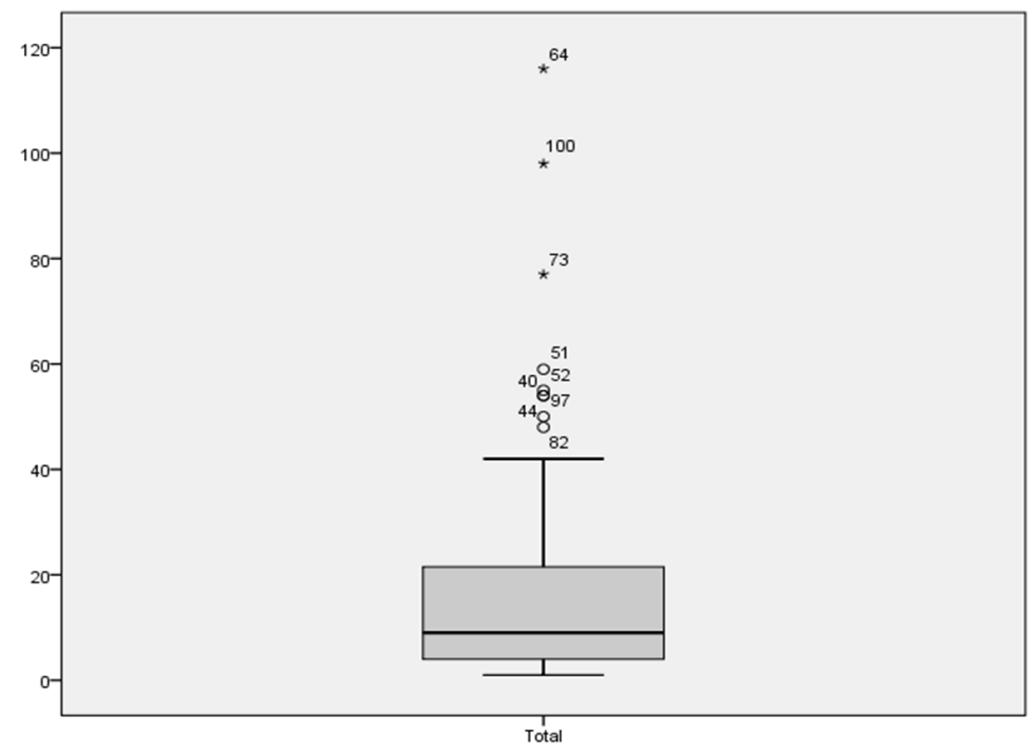

Figure 3. Distribution of All the Turns to Speak 


\subsection{The Comparative Rate of Verbal Manifestation of Each Mode of Thought}

Whatever the age for all the 1,246 occurrences coding the 1,730 pupil turns to speak studied, the proportion dedicated to each thought most actualized is, respectively, in favor of logical thought (781occurences/ 45\%), and creative thought (355 occururences/ $21 \%$ ), followed by responsible thought ( 212 occurences/12\%). Only $4.5 \%$ of the codings in the sample illustrate the presence of metacognitive thought ( 78 occurences) figure 4 , the gross number of occurrences is given beside each thought).

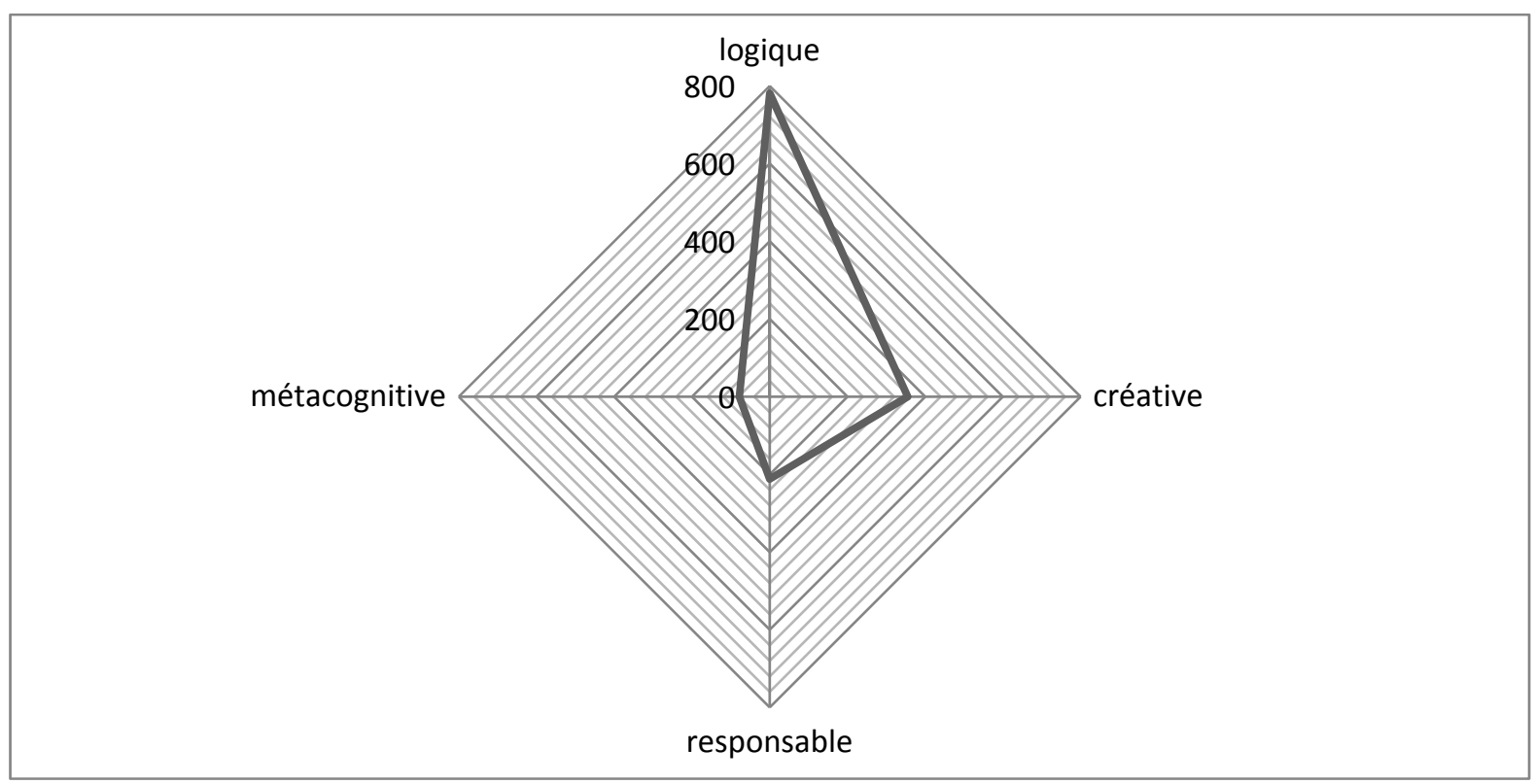

Figure 4. Respective Numbers of Verbalizations of Modes of Thought

\subsection{Qualitative Link Between the Modes of Thought and the Age Groups}

In line with our hypotheses we verify if the age groups differ (Chi2) at the level that the four modes of thought are manifested. For each mode we verify whether the use is (or not) related to the age or maybe to the gender (table 3 ). The comparative study of the modes of thought indicates that each mode is not sensitive in the same manner to the developmental effect: only the logical and responsible thoughts are sensitive to age - and indeed also depending on a gender effect (logical: $\mathrm{OR}=1.36$, Chi2 $=4.43, \mathrm{p}<.0 .04)$, with a similar trend for responsible thought $(\mathrm{OR}=1.64$, Chi2=3.27, $\mathrm{p}<.0 .07$ ).

Table 3. Summary of the Cumulative Logistic Regression Analyses for the Four Modes of Thought

\begin{tabular}{|c|c|c|c|c|c|}
\hline Variable & Odds-Ratio & $\begin{array}{c}\text { Confidence interval of the Odds-ratio } \\
\text { at } 95 \%\end{array}$ & $\chi^{2}$ & ddl & $\mathrm{P}$ \\
\hline \multicolumn{6}{|c|}{ Logical thought } \\
\hline Age & 1.121 & $1.048-1.200$ & 10.888 & 1 & 0.001 \\
\hline Girls vs. Boys & 1.360 & $1.021-1.811$ & 4.429 & 1 & 0.035 \\
\hline \multicolumn{6}{|c|}{ Creative thought } \\
\hline Age & 1.008 & $0.923-1.101$ & 0.031 & 1 & 0.862 \\
\hline Girls vs. Boys & 1.182 & $0.796-1.755$ & 0.687 & 1 & 0.407 \\
\hline \multicolumn{6}{|c|}{ Responsible thought } \\
\hline Age & 1.151 & $1.021-1.298$ & 5.257 & 1 & 0.022 \\
\hline Girls vs. Boys & 1.644 & $0.959-2.818$ & 3.271 & 1 & 0.071 \\
\hline \multicolumn{6}{|c|}{ Metacognitive thought } \\
\hline Age & 0.960 & $0.769-1.199$ & 0.131 & 1 & 0.718 \\
\hline Girls vs. Boys & 1.529 & $0.595-3.928$ & 0.778 & 1 & 0.378 \\
\hline
\end{tabular}

Beyond the rate of manifestation (see 3.2.), these results indicate that the logical, responsible, creative, and 
metacognitive thoughts do not manifest the same evolution from the ages of 10 to 18 .

\subsubsection{Evolution of the Logical Thought}

Five epistemological degrees are represented. The cumulative logistic regression analysis indicates a developmental effect $(\mathrm{OR}=1.12$, Chi2 $=10.89, \mathrm{p}<0.01)$. Reduced to a single scale (Figure 5) we display the developmental effect which concerns a progressive slide from pre-relativism (3) to relativism (4) quite clear from the ages of 10 to 13 - the 10 years group being quite differentiated from the 11-13; then we note the emergence of the post-relativist degree from 13 years. From this age degrees 3 and 4 seem to remain stable.

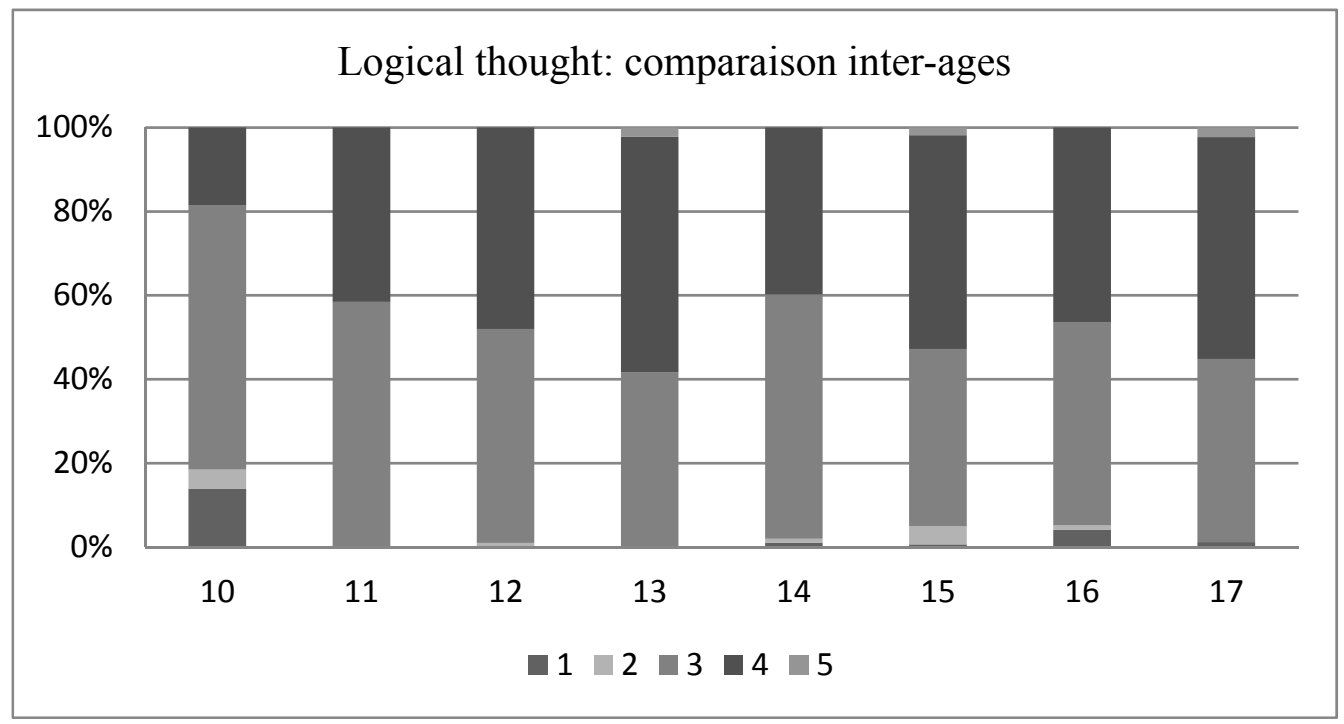

Figure 5. Manifestation of the Epistemological Degrees of Logical Thought According to Age Group

\subsubsection{Evolution of Creative Thought}

Four degrees are represented. The statistical analysis does not show any developmental effect $(\mathrm{OR}=1, \mathrm{Chi} 2=0.03$, $\mathrm{p}=0.86$ ). The figure 6 displays this lack of linear development.

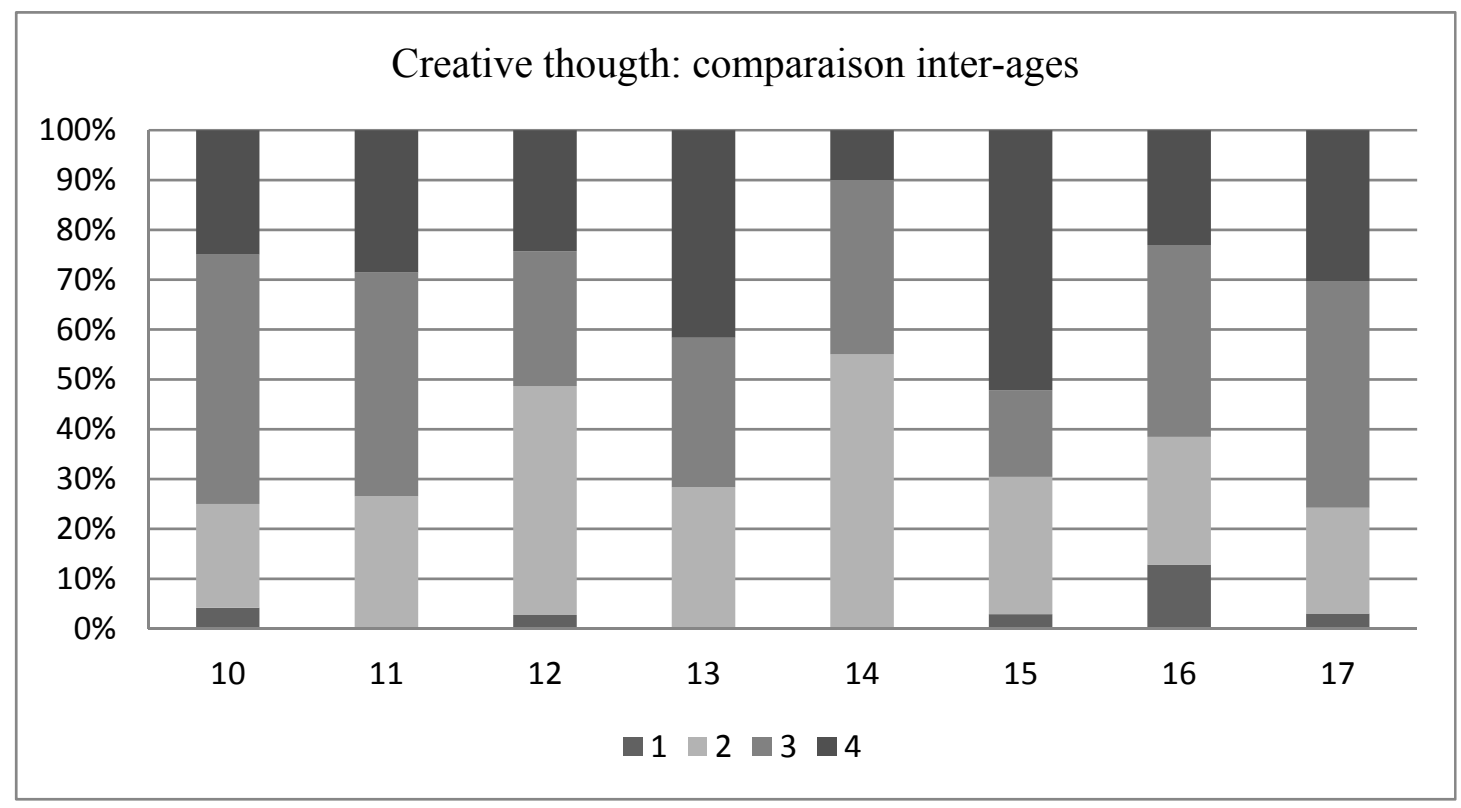

Figure 6. Manifestation of the Epistemological Degrees of Creative Thought According to Age Groups The proportion relating to the manifestation of post-egocentrism (degree 2), whatever the age, should be noted. 


\subsubsection{Evolution of Responsible Thought}

5 degrees are represented. The cumulative logistic regression analysis indicates a developmental effect ( $\mathrm{OR}=1.15$, Chi2 $=5.26, \mathrm{p}<0.03)$.

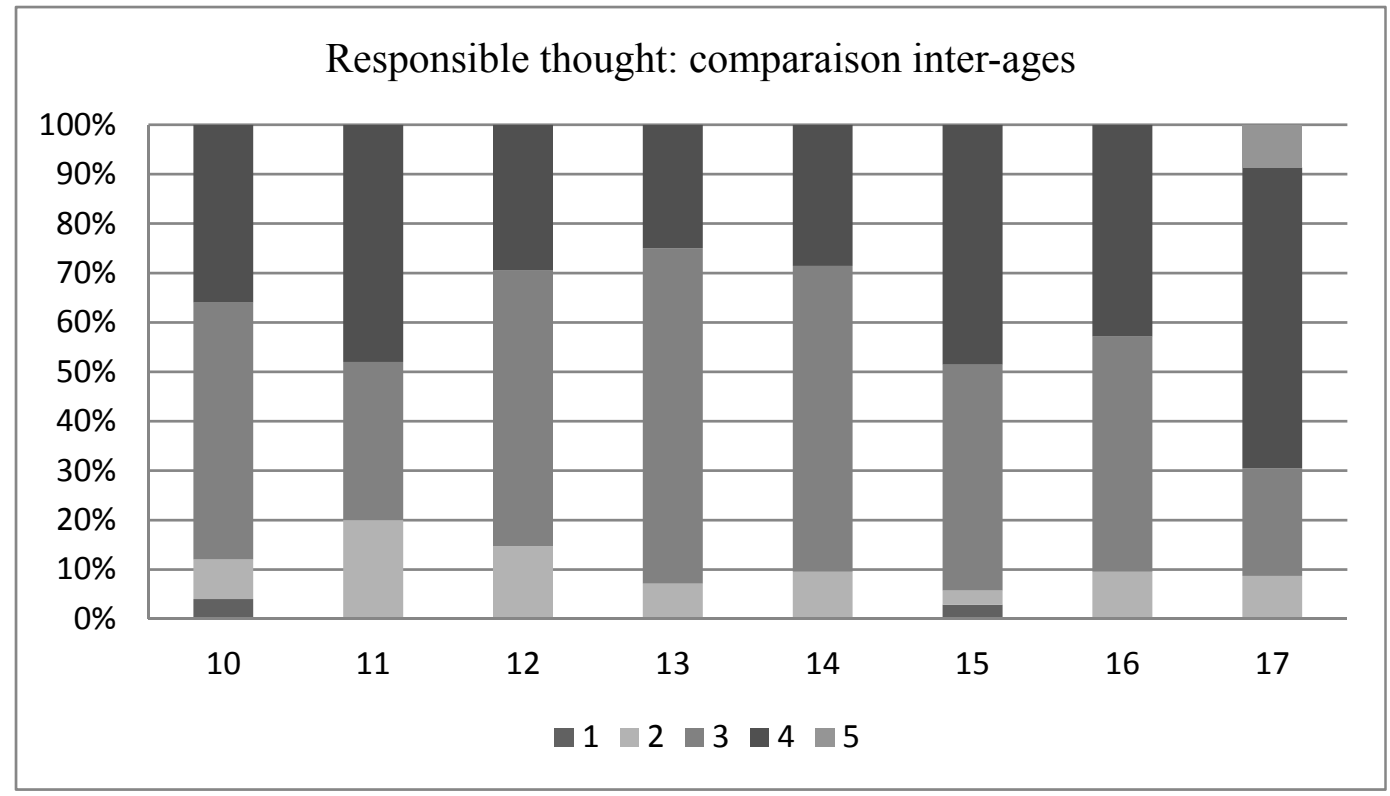

Figure 4anifestation of the Epistemological Degrees of Responsible Thought According to the Age Groups

From the ages of 12 to 14 the pre-relativist type degree takes up a large percentage, followed by the relativist from the age of 15, with the decline of the post-egocentric degree, to the clear advantage of the dominant relativist degree at 17 with post-relativism breaking through.

\subsubsection{Evolution of metacognitive thought}

For this thought hardly verbalized in the sample (as a reminder $4.5 \%$ of the coded occurrences) four epistemological degrees are represented. No developmental effect has been demonstrated by statistical analysis - as figure 8 clearly shows.

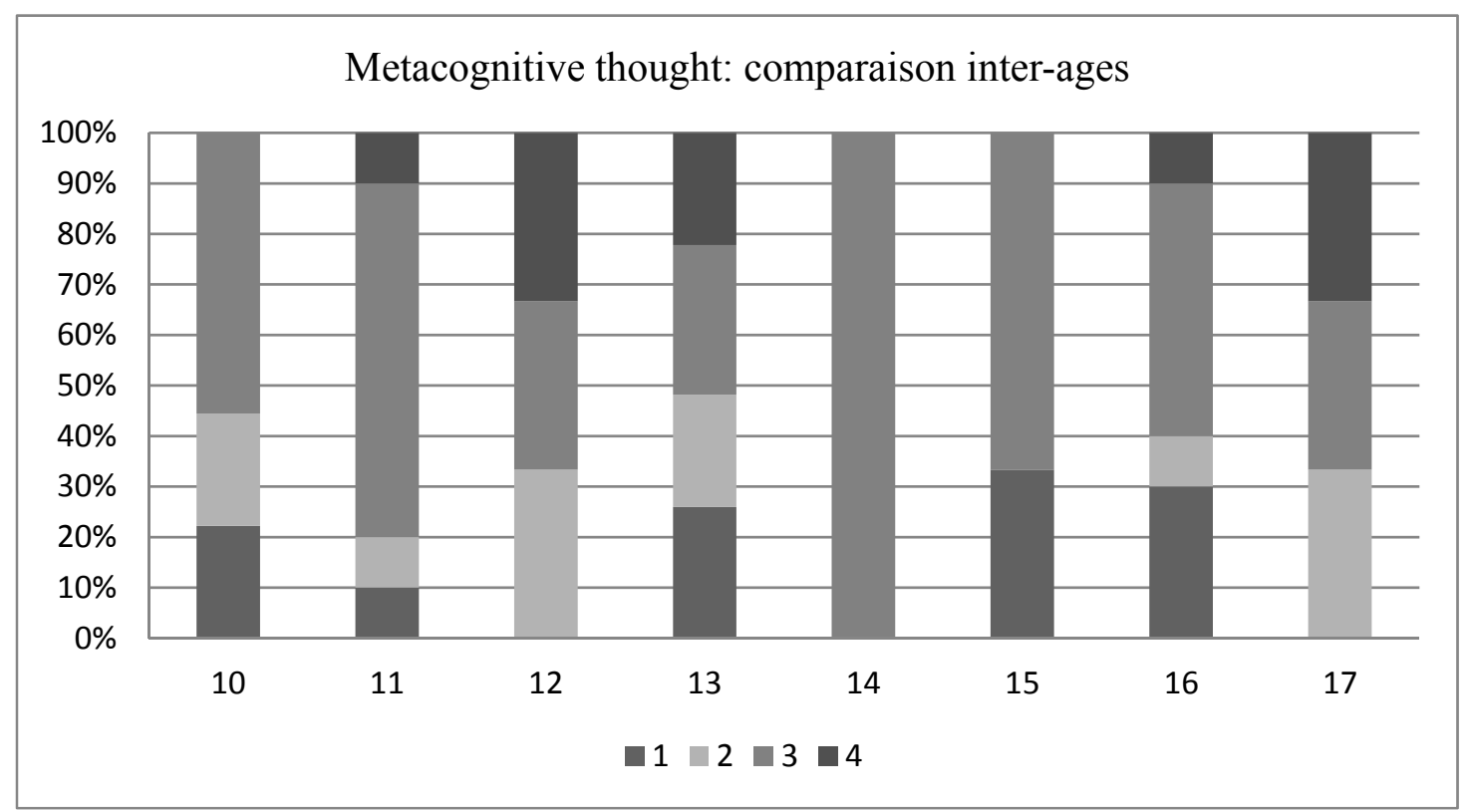

Figure 8. Manifestation of the Degrees of Metacognitive Thought According to the Age Groups 
The small number of occurrences concerned is an invitation to prudence as to any extrapolation. No trend can be identified.

\subsection{Influence of the Epistemological Degrees of One Thought Mode Manifested on Another}

In order to determine whether the four modes of thought are mobilized congruently we have determined, for each pupil, the highest epistemological degree he has used for each mode of thought. We have then tried to discover if a connection existed between these modes.

Fisher's exact tests reveal congruent uses of the responsible and logical thought $(p<0.01)$ and responsible and creative thoughts $(\mathrm{p}<0.01)$ with a strong relation $(\mathrm{phi}=0.68, \mathrm{~V}$ (of Cramér) $=0.48$ and $\mathrm{phi}=.68, \mathrm{~V}=0.39$ respectively). On the other hand, there is no connection between creative and logical thought $(\mathrm{p}=0.19)$, or with metacognitive thought.

In the case of significant relationships, the contingency tables (Table 4) indicate that the highest epistemological degrees a pupil uses are the same for both modes of thought (over- representation of the pupils in the shaded squares).

Table 4. Contingency Table for the Highest Epistemological Degree Used for the Mode of Thought

\begin{tabular}{|c|c|c|c|c|c|c|c|c|c|c|c|c|c|c|c|}
\hline & \multicolumn{6}{|c|}{ logical } & & & \multicolumn{6}{|c|}{ creative } \\
\hline & & 1 & 2 & 3 & 4 & 5 & Total & & & 1 & 2 & 3 & 4 & 5 & Total \\
\hline \multirow{6}{*}{ 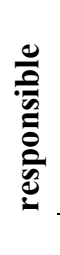 } & 1 & 0 & 0 & 0 & 0 & 0 & 0 & \multirow{6}{*}{ 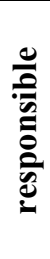 } & 1 & 0 & 0 & 0 & 0 & 0 & 0 \\
\hline & 2 & 0 & 0 & 1 & 2 & 0 & 3 & & 2 & 1 & 1 & 1 & 0 & 0 & 3 \\
\hline & 3 & 0 & 0 & 6 & 13 & 0 & 19 & & 3 & 0 & 3 & 5 & 8 & 0 & 16 \\
\hline & 4 & 0 & 0 & 2 & 38 & 4 & 44 & & 4 & 0 & 2 & 8 & 32 & 0 & 42 \\
\hline & 5 & 0 & 0 & 0 & 0 & 2 & 2 & & 5 & 0 & 0 & 1 & 1 & 0 & 2 \\
\hline & Total & 0 & 0 & 9 & 53 & 6 & 68 & & Total & 1 & 6 & 15 & 41 & 0 & 63 \\
\hline
\end{tabular}

\section{Discussion/Conclusion}

Taking the results presented as a whole it is apparent that logical thought occupies practically half the verbalizations, and thus seems to be the strong link in a discussion on a philosophical topic (as in our case - talking about freedom). Logical thought is, in addition, sensitive to development, like responsible thought, which in turn represents about $10 \%$ of the utterances: the more one grows up the more one becomes logical and responsible. The activated epistemology degree that both these modes of thought share seems to prepare the spontaneous accession at the age of 18 to the degree of 5 out of 6 on our scale: the epistemological congruence between these two modes of thought is borne out. Concerning linearity or developmental modifications (stagist vision, Piaget versus Vygotsky) our data therefore indicate rather a form of development fitting the epistemological degrees hierarchically together - at least for these thought modes that are sensitive to development - the logical and responsible modes.

Creative thought, manifested in nearly a quarter of the pupils' utterances, therefore second in terms of quantity, seems to have an epistemological congruence with responsible thought. Significantly not sensitive to the developmental effect, the pre-relativist to relativist perspectives seem to govern the period from ages 10 to 18 , enabling the pupils to activate divergent ideas/utterances connected not to their age but rather related to the ideas emitted by the other pupils. On the other hand, nothing allows one to suggest that the creativity has a natural link with logical thought (see Slade, 2000). As the epistemological degree associated with this thought is congruent with that of responsible thought, choosing the lever of responsibility may well be an important route for favoring the elevation of responsibility and creativity at the same time (see Kriemeen \& Hjaia, 2017).

As the poor relation of verbal manifestations metacognitive thought only leaves weak traces in the utterances given which is in line with the results already confirmed and the literature (see Daniel \& Gagnon, 2011, 2012; Heinzen, 2014).

In total, apart from a few extreme individuals (weak or strong verbalizers), for a median of nine turns to speak per individual, half the utterances (914 out of 1,730) correspond to the actualization of the collective thought. In this way, without specific intervention, without being based on a piece of teaching, but extracted in situation causing the comparison of diverging opinions (contradictory opinions proposed at the start, see methodology), the collective proposition is essentially constructed through confrontation with peers' propositions, progressively extended to a bit wider social context, but not providing reasons, or criteria, or discussing the value system underlying the ideas, choices, propositions emitted. Whilst the epistemology degree applied to responsible thought mediatizes the logical 
production on the one hand, and creativity into the bargain, the lack of expression of doubt (degree 6 of responsible thought) may block a possible elevation of the epistemology applied to logical and creative modes of thought, which between the two represent $75 \%$ of the verbalizations coded.

If the pupils do not doubt spontaneously, can the teacher not activate the doubts explicitly? Concerning the ordinary classes the results of the study carried out enable us to give the prognosis that if teaching programs provided the pupils - whether explicitly or implicitly - with reasons for "doubting" (more or less systematically) propositions emitted, the programs might favor the manifestation of higher epistemological degrees of responsibility, and - as a corollary - would constitute a visible, prominent obstacle which would entail the actualization of higher degrees concerning logic and creativity, and would help develop a metacognitive, self-corrective mode of thought.

\section{References}

Arendt, H. (1972). La crise de la culture: huit exercices de pensée politique. Paris, Gallimard.

Arendt, H. (1961/2016). Condition de l'homme moderne. Paris: Calman-Levy, 1961, Titre original The Human Condition, Réed Paris: Presses Pocket, 2016.

Auriac-Slusarczyk, E. (2010). Les interactions scolaires : actualités et méthodes, Revue Psychologie de l'Interaction, 27-28. Paris: L'harmattan.

Auriac-Slusarczyk, E., \& Coletta, J-M. (2015). Les ateliers de philosophie: une pensée collective en acte. Clermont Ferrand : Presses universitaires Blaise Pascal.

Auriac-Slusarczyk, E., \& Fiema G. (2013). Raisonner et discuter : définitions et principe d'étude pragmatique du corpus philosophèmes. Cahier du LRL, 5, 41-74.

Auriac-Slusarczyk, E., \& Leblay, C. (2010). Pourquoi travailler sur un corpus commun ? Pourquoi travailler de manière pluridisciplinaire? Synergies, Scandinaves, 5, 17-30.

Auriac-Peyronnet, E., \& Daniel, M.-F. (2002). The specifics of Philosophical Dialogue: A case Study of Pupils Aged 11 and 12 Years. Thinking, 16(1), 23-31. https://doi.org/10.5840/thinking20021615

Auriac-Slusarczyk, E., Adami, J., \& Daniel, M-F (2011). Tester les prédispositions à l'esprit critique au primaire. Psychologie \& Education, Avril 2011(1), 55-80.

Bautier, E., \& Rochex, J-Y. (1999). Henri Wallon. L'enfant et ses milieux. Paris : Hachette.

Baffrey-Dumont, V. (2000). Pensée post formelle, jugement réflexif et pensée réflexive. In R. Pallascio \& L. Lafortune, Pour une pensée réflexive en éducation, (pp.9-29). Sainte-Foy: Presses de l'Université du Québec

Beaudot, J. (1969). La créativité à l'école. Paris: Presses universitaires de France.

Beghetto, R. A., \& Plucker, J. A. (2016). Revisiting the relationship among schooling, learning, and creativity. In J. C. Kaufman and J. Baer. (Eds.), Creativity and Reason in Cognitive Development 2nd edition(pp.72-91). New York: Cambridge University Press. https://doi.org/10.1017/CBO9781139941969.005

Berland, L., \& McNeill, K. (2010). A learning progression for scientific argumentation: understanding student work and designing supportive instructional contexts. Science Education, 765-793. https://doi.org/10.1002/sce.20402

Bernicot, J., Veneziano, E. Musiol, M., \& Bert-Erboul, A. (2010). Interaction verbales et acquisition du langage. Paris: L'Harmattan.

Bernicot, J., Caron-Pargue, J., \& Trognon, A. (1997). Conversation interaction et fonctionnement cognitive. Nancy: Presses universitaires de Nancy.

Bernié, J.P. (2002). L'approche des pratiques langagières scolaires à travers la notion de « communauté discursive »: un apport à la didactique comparée? Revue française de pédagogie, 141(1), 77-88. https://doi.org/10.3406/rfp.2002.2917

Besançon M., Barbot, B., \& Lubart T. (2011). Évolution de l'évaluation de la créativité chez l'enfant de Binet à nos jours. Recherche \& Education, 5, 215-226.

Besançon, M., Guignard, J-H., \& Lubbart, T. (2006). Haut potentiel, créativité de l'enfant et éducation. Bulletin de psychologie, 59(5), 485, 491-503. https://doi.org/10.3917/bupsy.485.0491

Binet, A., \& Henri, V. (1895). La psychologie individuelle. L'Année Psychologique, 2, 415-465. https://doi.org/10.3406/psy.1895.1541 
Bronckart, J-P. (1985). Vygotsky, une oeuvre en devenir. In Vygotsky aujourd'hui (pp. 7-21). Paris: Delachaux et Niestlé.

Bronckart, J-P. (1997). Action, discours et rationalisation; l'hypothèse développementale de Vygotsky revisitée. In Outils et signes. Perspectives actuelles de la théorie de Vygotsky, (pp.. 199-221). Berne: P. Lang.

Bronckart, J-P. (2003). Constructivisme piagétien et interactionnisme vygotskien. Leurs apports à une conception des apprentissages et de la formation, in Pour une éducation postnationale (pp. 129-147). Bruxelles: Editions de l'Université de Bruxelles.

Bronckart, J-P., John-Steiner, V., Panofsky, C-P., Piaget, J., Scheuwly, B., Vygotski, L.S., \& Wertsh, J.V. (1985). Vygotski aujourd'hui. textes de base en psychologie, Neuchâtel. Paris, Delachaux \& Niestlé.

Brossard, M., \& Fijalkow, J. (1998). Apprendre à l'école: perspectives piagétiennes vygotskiennes. Bordeaux: presses universitaires de Bordeaux.

Bruchon, Y. (2005). Métacognition et retour réflexif. Retour aux sources, dans M. Dericke et E. Bautier, Culture(s) et Réflexivité, (pp.33-55). Saint-Etienne: publications de l’Université de Saint Etienne Jean Monnet.

Bereiter, C., \& Scardamalia, M. (2014). Knowledge Building and Knowledge Creation: One Concept, Two Hills to Climb. In S.C. Tan, H.J. So, J. Yeo (Eds.), Knowledge creation in education, (pp.35-52). Singapore: Springer. https://doi.org/10.1007/978-981-287-047-6_3

Cappeau, P., \& Seijido, M. (2005). Inventaire des corpus oraux en langue française, Projet DGFLF, in G. Smale, Présentation «Interactions et Corpus oraux ». Pratiques 147-148, 2010, 3-16.

Clark, H.H. (1996). Using language. Cambridge: Cambrige University Press. https://doi.org/10.1017/CBO9780511620539

Coirier, P., Gaonac'h, D., \& Passerault, J-M. (1996). Psycholinguistique textuelle. Paris: Armand Colin.

Cuypers, S., \& Haji, I. (2006). Education for critical thinking: can it be non-indoctrinative? Educational Philosophy and Theory, 38(6), 723-743. https://doi.org/10.1111/j.1469-5812.2006.00227.x

Daniel, M-F. (2017). Dignité humaine et Pensée critique dialogical chez des enfants et des adolescents, Éthique en éducation et en formation. Les dossiers du GREE, 3(3), 1-22.

Daniel, M-F. (2013). Pensée critique: pourquoi et comment faire progresser la pensée des élèves au-delà du relativisme?, Diotime, 57, p.19.

Daniel, M-F. (2005). Pour l'apprentissage d'une pensée critique au primaire. Sainte-Foy: Presses de l'Université du Québec.

Daniel, M-F. (1992/1997). La philosophie et les enfants, Les modèles de Lipman et de Dewey. Montréal, Ed. Logiques et Bruxelles: Eds. DeBoeck et Belin, 1992. Réédité en 1997.

Daniel, M-F., \& Auriac, E. (2011). La philosophie pour enfants est-elle de la "vraie" philosophie ?, Diotime, 47(1), 23.

Daniel, M-F., \& Auriac-Slusarczyk, E. (2011). Philosophy, Critical Thinking and Philosophy for Childre. Educational Philosophy and Theory, 43(5), 415-435. https://doi.org/10.1111/j.1469-5812.2008.00483.x

Daniel, M-F., \& Fiema, G. (2017a). Etude des perspectives épistémologiques sous-jacentes au processus de mobilisation d'une critical thoughtdialogical chez un groupe de philosophants âgés de 9 à 11 ans, dans J.P. Simon \& M. Tozzi, Paroles de philosophes en herbe (pp.185-206). Grenoble, UGA - Université Grenoble Alpes- Editions.

Daniel, M-F., \& Fiema, G. (2017b). Dialogical Critical Thinking in Children, Knowledge Cultures. Knowledge Cultures, 5(4), 42-65. https://doi.org/10.22381/KC5420174

Daniel, M-F., \& Gagnon, M. (2016). Dialogical Critical Thinking with 5 to 12 years old Pupils: A Continuous Epistemological Development. In G. Gibson (ed.), Critical Thinking: Theories, Methods and Challenges (pp. 45-76). New-York: Nova Science Publishers Inc.

Daniel, M.-F., \& Gagnon, M. (2011). A developmental model of dialogical critical thinking in groups of pupils aged 4 to 12 years. Creative Education, 2(5), 418-428. https://doi.org/10.4236/ce.2011.25061

Daniel, M.F., Belghiti, K., \& Auriac-Slusarczyk, E. (2017). Philosophy for Children and the Incidence of Teachers' Questions on the Mobilization of Dialogical Critical Thinking in Pupils. Creative Education, 8, 870-892. 
https://doi.org/10.4236/ce.2017.86063

Daniel, M-F., Pettier, J-C., \& Auriac-Slusarczyk, E. (2011). The Incidence of Philosophy on Discursive and Language Competence in Four-Year-Old Pupils. Creative Education, 2(3), 296-304. https://doi.org/10.4236/ce.2011.23041

Daniel, M.-F., Lafortune, L., Pallascio, R., Splitter, L., Slade, C., \& De la Garza, T. (2005). Modeling the development process of dialogical critical thinking in pupils aged 10 to 12 years. Communication Education, 54, 334-354. https://doi.org/10.1080/03634520500442194

Darling, L. (2006). Teaching social studies as if it matters: Young children and moral deliberation. In E. Ross (ed.), The social studies curriculum: Purposes, problems, possibilities. Albany: State University of New-York Press.

Darling, L. (2002). The essential moral dimensions of citizenship education: what should we teach? Journal of Educational thought, 36(3), 229-249.

Derycke, M., \& Bautier, E. (2005). Culture(s) et Réflexivité. Saint-Etienne: publications de l'Université de Saint Etienne Jean Monnet.

Descombes, V. (2014). Le parler soi. Implications philosophiques. Paris, Gallimard.

Descombes, V. (2013). Exercices d'humanités. Paris: Les dialogues des petites Platons.

Ennis, R. (1994). Assessing critical thinking dispositions: theoretical considerations. Texte présenté à AERA. New Orleans: LA.

Ennis, R. (1993). Critical thinking assessment. Theory into Practice, 32(3), 179-186. https://doi.org/10.1080/00405849309543594

Esperet, E. (1991). Psychologie du langage et gestion cognitive des activités langagières. In Vergnaud G, (1991), Les sciences cognitives en débat (pp. 207-217). Paris: Éditions du CNRS,

Espéret, E. (1990). De l'acquisition du langage à la construction des conduites langagières. In G. Netchine-Grynberg (dir.) Développement et fonctionnement cognitifs de l'enfant. Des modèles généraux aux modèles locaux (pp. 121-135). Paris: presses universitaires de France.

Esperet, E. (1979). Intelligence verbale et milieu social. Bulletin de Psychologie, 340(32)(8-14), 475-485

Esperet, E., \& Guibourg, V. (1988). Adaptation du langage de l'entourage et développement linguistique de l'enfant : la recherche de styles maternels interactifs. Bulletin de Psychologie, 388(42) (1-5), 57-65.

Fagot, M. (2000/2001). Alfred Binet et l'invention des tests d'intelligence, Sciences Humaines, Hors série, 30.

Flavell, J.H. (1976). Metacognitive aspects of problem-solving, (pp. 231- 235). Hillsdate, New Jersey: Lawrence Erlbaum.

Flores, K., Matkin, G., Burbach, M., Quinn, C., \& Heath, H. (2012). Deficient critical thinking skills among college graduates: implications for leadership. Educational Philosophy and Theory, 44(2), 212-230. https://doi.org/10.1111/j.1469-5812.2010.00672.x

Fong, B. (2002). Of character and citizenship. Peer Review, 4, 8-10.

Forges, R. (2013). Formation initiale des enseignants en enseignement de l'éducation physique et à la santé: Étude des manifestations d'une critical thoughtvisée, stimulée et manifestée. Doctoral thesis. Montreal (Quebec City) Canada : Université de Montréal.

Ghiglione, R., \& Blanchet, A. (1991). Analyse de contenu et contenus d'analyses. Paris: Dunod.

Ghiglione, R., Kekenbosh, C., \& Landré, A. (1995). L'analyse cognitive-discursive. Grenoble: Presse universitaires de Grenoble.

Guilford, J-P. (1967). The nature of human intelligence. McGraw Hill.

Gregory, M-R., Hayes, J., \& Murris, K. (2017). The Routeledge International Handbook of Philosophy for Chidren. London and New York: Taylor \& Francis Group.

Harpaz, Y. (2010). Conflicting Logics in Teaching Critical Thinking. Summer, 25(2), 5-16. https://doi.org/10.5840/inquiryctnews20102527

Heinzen, S. (2014). Processus de la critical thoughten éthique chez des élèves de 14-15 ans au travers du débat philosophique. Communication presented at the colloquium. Les discussions philosophiques de 5 à 18 ans en 
milieu scolaire. Quels regards des sciences humaines et sociales? Clermont-Ferrand, France. June.

Huteau, M. (2001a, dir.) Les figures de l'intelligence. Paris: Editions et Applications psychologiques.

Huteau, M. (2001b). La question de l'intelligence aujourd'hui. In M. Huteau, Les figures de l'intelligence, (pp.9-17). Paris, Editions et Applications psychologiques.

Inhelder, B., \& Piaget, J. (1955). De la logique de l'enfant à la logique de l'adolescent. Paris: Presses universitaires de France.

Jaubert, M., \& Rebière, M. (2000). Le rôle des pratiques langagières dans la construction de savoirs en biologie Comment permettre aux élèves d'entrer dans une communauté discursive scientifique scolaire. Rapport de la recherche INRP «SCIENSCRIT - L'écriture en sciences ». Paris: Eds CNRS.

Kaufman, J-C., \& Baer, J. (2016). Creativity an Reason in Cognitive Development, (pp.3-96) Second Edition. Cambridge: Cambridge University Press. https://doi.org/10.1017/CBO9781139941969

Karmiloff-Smith, A. (1994). Précis of Beyond Modularity: A Developpemental Perspective on Cognitive Science. Behavioral and Brain Sciences, 17, 693-745. https://doi.org/10.1017/S0140525X00036621

Karmiloff-Smith, A. (1992). Beyond Modularity: A Developpemental Perspective on Cognitive Science. Cambridge: Cambrige University Press.

Karmiloff-Smith, A. (1979). A Funtional Approach to Child Language: A Study of Determiners and Reference. Cambridge: Cambridge University Press.

Kuhn, D. (2009). Do students need to be taught how to reason? Educational Research Review, 4, 1-6. https://doi.org/10.1016/j.edurev.2008.11.001

Kuhn, D., \& Pease, M. (2008). What needs to develop in the development of inquiry skills? Cognition and Instruction, 26, 512-559. https://doi.org/10.1080/07370000802391745

Kuhn, D., \& Pease, M. (2006). Do children and adults learn differently? Journal of Cognition and Development, 5 , 279-293. https://doi.org/10.1207/s15327647jcd0703_1

King, P., \& Kitchener, K. (2011). The reflexive judgment model: Twenty years of research on epistemic cognition. In B. Hofer \& P. Pintrich (eds.), Personal epistemology. The psychology of beliefs about knowledge and knowing (pp. 37-63). New York: Routledge.

King, P., \& Kitchener, K. (1994). Developing reflexive judgment: understanding and promoting intellectual growth and critical thinking in adolescents and adults. San Francisco: Jossey-Bass Publishers.

Kuhn, D., Cheney, R., \& Weinstock, M. (2000). The development of epistemological understanding. Cognitive Development, 15, 309-328. https://doi.org/10.1016/S0885-2014(00)00030-7

Kriemenn, H., \& Hajaia, S. (2017). Social Intelligence of Principals and Its Relationship with Creative Behavior. World Journal of Education, 7(3).

Lafortune, L., \& Roberton, A. (2004). Métacognition et pensée critique : une démache de mise en relation pour l'intervention, in R. Pallascio, M-F. Daniel \& L. Lafortune (dir.), Pensée et réflexivité. Théories et pratiques. Quebec : Presses de l'université du Québec.

Léon, J. (2008). Aux sources de la «Corpus Linuigstics» : First et la London School. In M. Cori, S. David, \& J. Léon (Eds.), Construction des faits en linguistique : la place des corpus, Langage, 171, 12-33.

Lechasseur, K. (2015). Modélisation de la mobilisation des savoirs par une critical thoughtchez des étudiantes en sciences infirmières lors de stages cliniques. In G. Kpazaï (ed.), Pensée critique et innovations dans la formation universitaire (pp.109-137). Montreal: Éditions Peisaj.

Leleux, C. (2005). La philosophie pour enfants. Le modèle de Matthew Lipman en discussion. Bruxelles: Ed. DeBoeck \& Larcier.

Lipman, M. (2003). Thinking in Education (2nd ed.). Cambridge: Cambridge University Press. https://doi.org/10.1017/CBO9780511840272

Lipman, M. (1995). A l'école de la pensée, trad. N. Decostre. Bruxelles: DeBoeck \& Larcier.

Lipman, M. (1988). Critical thinking: What can it be? Educational Leadership, 46(1), 38-43.

Lubart, T., Besançon, M., \& Barbot, B. (2011). Evaluation du Potentiel Créatif. Paris: Eds. Hogrefe. 
MacArthur, C-A., Graham, S., \& Fitzgerald, J. (2006, Eds.). Handbook of Writing Research. New York, London: The Guilford Press.

Marcos, H., Salasar-Orvig, A., Bernicot, J., Guidetti, M., Hudelot, C., \& Préneron, C. (2004). Apprendre à parler: influence du mode de garde. Paris: L'Harmattan.

McPeck, J. (1994). Critical thinking and the 'Trivial Pursuit' theory of knowledge. In K. Walters (Ed.), Re-Thinking reason: new perspectives in critical thinking (pp. 101-117). Albany, NY: State University of New York Press.

McPeck, J. (1981). Critical thinking and education. Oxford: Martin Robertson.

Paul, R. (1993a). The logic of creative and critical thinking. American Behavioural Scientist, 37(1), 21-39. https://doi.org/10.1177/0002764293037001004

Paul, R. (1993b). Critical thinking: What every person needs to survive in a rapidly changing worl. Santa Rosa, CA: Foundation for Critical Thinking.

Paul, R. (1992). Critical Thinking: What, Why and How. New directions for community college, 77, 3-25. https://doi.org/10.1002/cc.36819927703

Peters, M., Smith, M., \& Smith, G. (2002). Use of critical interactive thinking exercises in teaching reproductive physiology to undergraduate students. American Society of Animal Science, 80, 862-865. https://doi.org/10.2527/2002.803862x

Piaget, J. (1974). Réussir et comprendre. Paris: Presses universitaires de France.

Piaget, J. (1971). Problèmes de psychologie génétique. Paris: Presses universitaires de France.

Plucker, J-A., \& Beghetto, R-A. (2015). Special Issue Editor Creativity and Education, Psychology of Aesthetics, Creativity, and the Arts, 9(2), 113-114. https://doi.org/10.1037/aca0000020

Plucker, J.A., Beghetto, R-A., \& Dow, G.T. (2010). Why Isn't Creativity More Important to Educational Psychologists? Potentials, Pitfalls, and Future Directions in Creativity Research. Educational Psychologist, $39(2), 8$.

Pons, F., Doudin, P-A, Martin, D., Lafortune, L., \& Harris, P. (2004). Psychogénèse de la conscience et de la pensée réflexive. In R. Pallascio, M-F. Daniel \& L. Lafortune, Pensée et réflexivité. Théories et pratiques (pp.13-36). Sainte-Foy: Presses de l'Université du Québec.

Rochex, J-Y. (1997). L'oeuvre de Vygotski : fondements pour une psychologie historico-culturelle. Revue française de pédagogie, 120, 105-14. https://doi.org/10.3406/rfp.1997.1161

Salazar-Orvig, A., \& Hudelot, C. (1989). Enchaînements, continuités et déplacements dialogicals chez le jeune enfant, Verbum, XII(1), 99-115.

Siegel, H. (1988). Educating reason: Rationality, critical thinking and education. New York: London: Routledge.

Simon, J-P., \& Tozzi, M. (2017). Paroles de philosophes en herbe. Grenoble: UGA Editions.

Slade, C. (2000). Pensée critique et créative. In R. Pallascio \& L. Lafortune (dir), Pour une pensée réflexive en éducation. Sainte-Foy: Presses Universitaires du Québec.

Sorsana, C. (1999). Psychologie des interactions sociocognitives. Paris: A. Colin.

Tabak, I., \& Weinstock, M. (2008). A sociocultural exploration of epistemological beliefs. In M. Khine (ed.), Knowing, Knowledge and Beliefs: Epistemological Studies across Diverse Cultures (p. 177-195). New York, NY: Springer Science/Business Media. https://doi.org/10.1007/978-1-4020-6596-5_8

Thomas, N. (2001). Democratic education: A matter of institutional conscience and skills. About Campus, 6, 19-24.

Thommen, E., \& Rimbert, G. (2005). L'enfant et les connaissances sur autrui. Paris: Ed. Belin Supérieur.

Torff, B. (2006). Expert teachers beliefs about use of critical-thinking activities with high-and low-advantage learners. Teacher Education Quaterly, Printemps, 37-52.

Trognon A., \& Brassac C. (1992). L'enchaînement conversationnel. Cahiers de linguistique française, 13, 76-107.

Veneziano, E. (1999). La conversation, Instrument, objet et source de connaissance. Paris: L’Harmattan.

Vergnaud, G. (2000). Lev Vygotski. Pédagogue et penseur de notre temps. Paris: Hachette.

Villalba, V. (2008). On Creativity. Towards an Understanding of Creativity an its Measurements, JRC Scientific and 
Technological Reports, Luxembourg. Publications of the European Communities.

Vygotski, Lev- S. (1934/1997). Myslenic i rec', trad. fr. F.Sève, Pensée et Langage. Paris: La dispute.

Williams, G. (2005). La linguistique de corpus. Rennes: Presses universitaires de Rennes.

Wilson, R. C., Guilford, J. P., \& Christensen, P. R. (1953). The measurement of individual differences in originality. Psychological Bulletin, 50(5), 362-370. https://doi.org/10.1037/h0060857

Wittgenstein, L. (1921/1961). Tractatus logico-philosophicus. Investigations philosophiques, trad. fr., Traité logique et philosophique. par Pierre Klossowski. Paris: Gallimard.

Wolfs, J-L. (2005). Métacognition et réflexivité dans le champ scolaire: origines des concepts, analyse critique et perspectives. In M. Derycke, Culture(s) et réflexivité (pp.21-55). Saint Etienne: publications de l'université de St Etienne.

Worms, F. (2017). Henri Bergson. L'évolution du problème de la liberté. Cours au Collège de France 1904-1905. Paris: Presses universitaires de France.

\section{Notes}

Note 1. The research projects underlying this article were subsidized by the Social Sciences and Humanities Research Council of Canada (\#410-229-0028 and \#435-2013-0212).

Note 2. for "nothing immense is left in what can be measured" (Arendt, 1961/2016, p.318).

Note 3. Daniel conductes research projects with teams of researchers from Canada, France, Mexico and Australia. Participants were groups of pupils from kindergarten and elementary school who had practiced with $\mathrm{P} 4 \mathrm{C}$ for at least one school year at a frequency of one hour per week. The qualitative methodology comes from Grounded Theory. The goal was to map out a CT development process in apprentice philosophers that could subsequently be used as a tool for analyzing exchanges between pupils.

Note 4. Involving at the time Australia, Mexico and Quebec for the classes of students aged 11-12.

Note 5. Lipman was already saying: "fortunately, also, it is now too late to back-track" inviting us to understand that at present man is questioning himself humanly about his capacities and that our time has to take a position about measuring intelligence.

Note 6. In the educational programs that claim it as a reference the teachers cause the metacognition.

Note 7. We could have illustrated with each of the age groups. The age 13/14 is chosen randomly to account for the slight variability that corresponds to an adaptation by the class-leader in situation.

Note 8 . The coding revisions are not equivalent depending on the eges. In gross numbers they represent respectively: 10/11 years: 6 ; $11 / 12$ years: $9 ; 12 / 13$ years: $53 ; 13 / 14$ years: $63 ; 14 / 15$ years: $55 ; 15 / 16$ years: $74 ; 16 / 17$ years: 67 and 17/18 years: 12 .

Note 9. The hubbub and inaudible speech are eliminated from this breakdown. 
Appendix 1: Operational Model of the Developmental Process of Dialogical Critical Thinking, according to

Daniel, 2013

\begin{tabular}{|c|c|c|c|c|}
\hline $\begin{array}{l}\text { MODE/ } \\
\text { EPISTEMOLOGICAL } \\
\text { PERSPECTIVE }\end{array}$ & LOGICAL & CREATIVE & RESPONSIBLE & $\begin{array}{c}\text { META-COGNITI } \\
\text { VE }\end{array}$ \\
\hline EGOCENTRICITY & $\begin{array}{l}\text { Statement based on } \\
\text { the perceptual } \\
\text { experience of a } \\
\text { specific and personal } \\
\text { fact. }\end{array}$ & $\begin{array}{l}\text { Statement that } \\
\text { gives meaning to } \\
\text { a personal and } \\
\text { concrete point of } \\
\text { view. }\end{array}$ & $\begin{array}{l}\text { Statement that is } \\
\text { related to a } \\
\text { personal and } \\
\text { specific behavior } \\
\text { tied to a social or } \\
\text { moral belief. }\end{array}$ & $\begin{array}{l}\text { Retrospective } \\
\text { statement about a } \\
\text { personal and } \\
\text { specific task, } \\
\text { point of view, } \\
\text { feeling, etc. }\end{array}$ \\
\hline $\begin{array}{l}\text { POST-EGOCENTRICIT } \\
\mathrm{Y}\end{array}$ & $\begin{array}{l}\text { Statement based on } \\
\text { experience (personal } \\
\text { or someone close) }+ \\
\text { reasoning. }\end{array}$ & $\begin{array}{l}\text { Statement that } \\
\text { gives meaning to } \\
\text { a personal point } \\
\text { of view (but } \\
\text { distanced from } \\
\text { self). }\end{array}$ & $\begin{array}{l}\text { Particular/ } \\
\text { concrete } \\
\text { statement tied to a } \\
\text { moral or social } \\
\text { rule (learned). Not } \\
\text { contextualized. }\end{array}$ & $\begin{array}{l}\text { Retrospective } \\
\text { statement about a } \\
\text { personal task, } \\
\text { point of view, } \\
\text { feeling, etc. } \\
\text { (distanced from } \\
\text { self). }\end{array}$ \\
\hline PRE-RELATIVISM & $\begin{array}{l}\text { Somewhat } \\
\text { generalized statement } \\
\text { that is not justified or } \\
\text { with an implicit, } \\
\text { circular or false } \\
\text { justification. }\end{array}$ & $\begin{array}{l}\text { Statement that is } \\
\text { new, divergent or } \\
\text { that presents } \\
\text { different } \\
\text { situations/ } \\
\text { solutions/ } \\
\text { hypotheses (units) } \\
\text { in relation to a } \\
\text { personal idea or to } \\
\text { someone else's } \\
\text { idea (peer or text). }\end{array}$ & $\begin{array}{l}\text { Statement linked } \\
\text { to a somewhat } \\
\text { generalized action } \\
\text { in a moral or } \\
\text { social perspective. }\end{array}$ & $\begin{array}{l}\text { Descriptive } \\
\text { retrospective of a } \\
\text { personal task, } \\
\text { point of view, } \\
\text { feeling, etc. } \\
\text { (distanced from } \\
\text { self). }\end{array}$ \\
\hline RELATIVISM & $\begin{array}{l}\text { Incomplete or } \\
\text { concrete justification } \\
\text { (explanation)/reason-i } \\
\text { ng based on } \\
\text { experience. }\end{array}$ & $\begin{array}{l}\text { Relationship that } \\
\text { gives meaning to } \\
\text { a peer's point of } \\
\text { view (by } \\
\text { completing it or } \\
\text { adding a nuance). }\end{array}$ & $\begin{array}{l}\text { Statement that } \\
\text { explains a will to } \\
\text { understand/ } \\
\text { include others } \\
\text { (from the } \\
\text { immediate } \\
\text { environment). } \\
\text { (Contextualized). }\end{array}$ & $\begin{array}{l}\text { Descriptive/expla } \\
\text { natory } \\
\text { retrospective of } \\
\text { another person's } \\
\text { task, thought, etc. } \\
\text { (immediate } \\
\text { environment). }\end{array}$ \\
\hline $\begin{array}{l}\text { POST-RELATIVISM/ } \\
\text { PRE-INTERSUBJECTI } \\
\text { VITY }\end{array}$ & $\begin{array}{l}\text { Justification based on } \\
\text { "good } \\
\text { reasons"/simple } \\
\text { reasoning. }\end{array}$ & $\begin{array}{l}\text { Relationship that } \\
\text { presents a } \\
\text { different context } \\
\text { that takes into } \\
\text { account the } \\
\text { group's } \\
\text { perspective. }\end{array}$ & $\begin{array}{l}\text { Statement that } \\
\text { justifies a desire } \\
\text { to understand/ } \\
\text { include others } \\
\text { (distant } \\
\text { environment). } \\
\text { (contextualized) }\end{array}$ & $\begin{array}{l}\text { Descriptive/ } \\
\text { explanatory } \\
\text { retrospective of } \\
\text { another person's } \\
\text { task, thought, etc. } \\
\text { (distant } \\
\text { environment). }\end{array}$ \\
\hline INTERSUBJECTIVITY & $\begin{array}{l}\text { Justification based on } \\
\text { criteria. } \\
\text { Conceptualization } \\
\text { based on evaluative } \\
\text { reasoning. }\end{array}$ & $\begin{array}{l}\text { Evaluative } \\
\text { relationship that } \\
\text { provides a } \\
\text { different meaning } \\
\text { and transforms } \\
\text { the perspective. }\end{array}$ & $\begin{array}{l}\text { Doubt that } \\
\text { underlies the } \\
\text { evaluation of } \\
\text { categories (rules, } \\
\text { principles, } \\
\text { social/moral } \\
\text { values). } \\
\text { Categorization }\end{array}$ & $\begin{array}{l}\text { Evaluative } \\
\text { statement that } \\
\text { expresses a } \\
\text { change in } \\
\text { perspective } \\
\text { following the } \\
\text { integration of } \\
\text { criticism. } \\
\text { Correction }\end{array}$ \\
\hline
\end{tabular}


Appendix 2: detail of the spoken interventions per pupil and per age group for each mode of thought

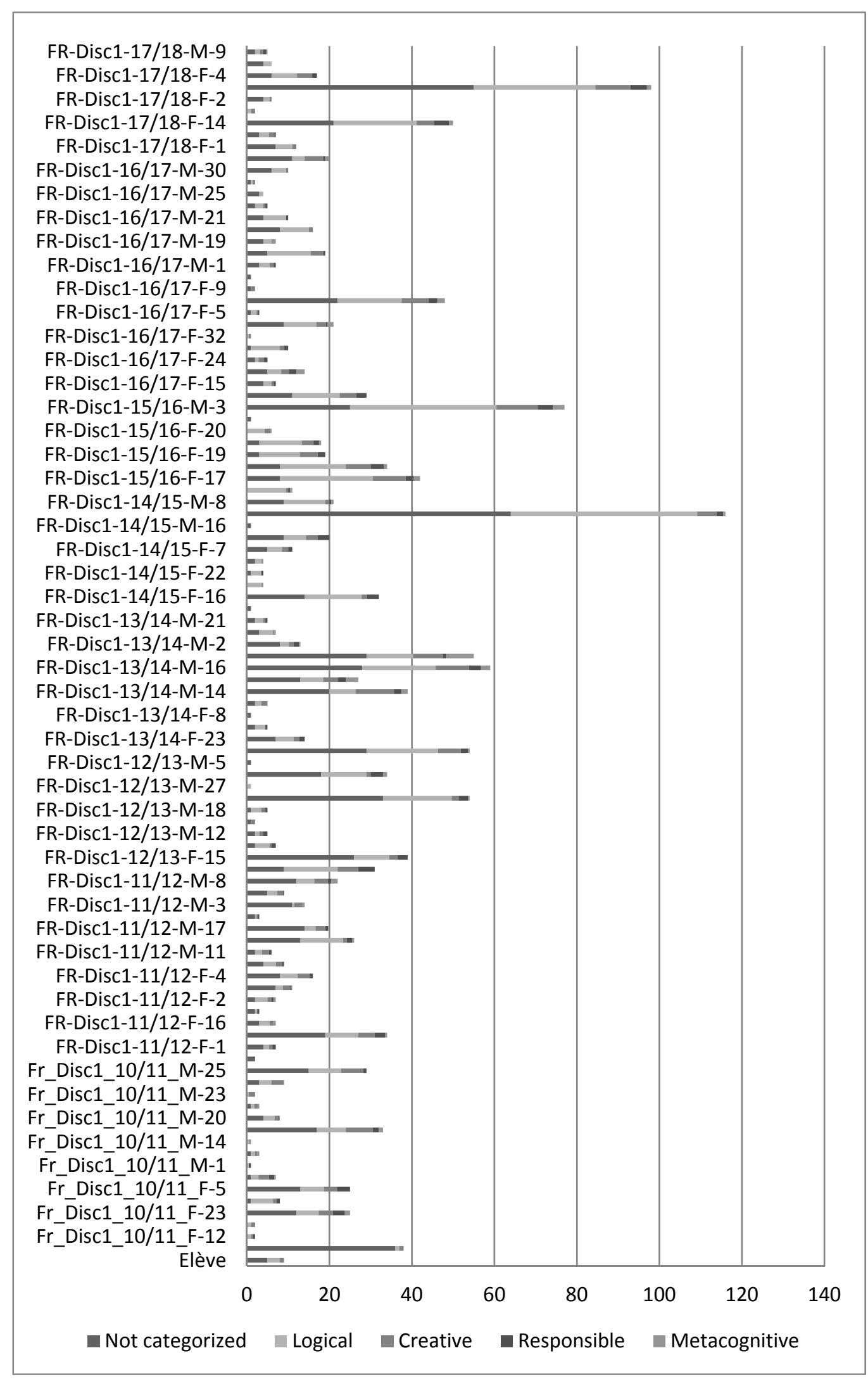

